\title{
Private Capital and Investment Climate for Economic Growth: Empirical Lessons based on ARDL bound test technique
}

\author{
By Gérard Tchouassi ${ }^{1}$
}

\begin{abstract}
:
Using time series, autoregressive distributed lags (ARDL)-bound test approach and errorcorrection model (ECM), this paper aims to analyze how private capital and investment climate contribute to economic growth in African countries: Cameroon, Côte d'Ivoire, Tunisia, South Africa and Zambia. We find that in short-run there is a significant relationship between private capital, economic freedom and economic growth in Cameroon, in Côte d'Ivoire, in South Africa and in Zambia. In long run, we establish that a long term relationship exists between the variables. This implies that there is a long run cointegration relationship among the variables in some equations in Cameroon, Côte d'Ivoire, South Africa and Zambia. Employing the appropriate order of the ARDL specification and multidimensional economic freedom proxies to examine this linkage, the results obtained are not all significant.
\end{abstract}

JEL Classifications: C13, C22, E22, F43, O11, O47

Key-Words: Private capital, Investment climate, Economic freedom, Economic growth, Time series, ARDL bound test approach, Error-Correction Model.

\section{Introduction}

Private capital and investment climate are central drivers to achieving and regenerating strong, sustainable and balanced economic growth in developing world. The main challenge for developing countries and since many years was to provide, sustain and enable business environment for domestic and foreign investments. Foreign aids, public and private capitals used by the governmental and the private sectors are stilled actually in debate since the strategy of great investments called big push (RosensteinRodan, 1943; Easterly, 2005). Given the past and the current development paradigm, is the private sector with private capitals one of the key engines for economic growth in Africa? In the literature we find various typologies of capital flows. The flows can resulted from a foreign investor's decision or from a national investor's decision and can be seen as inward or outward flows, respectively.

Department of Economics, Faculty of Economics \& Management, University of Yaoundé IISoa, Yaoundé, Cameroon. 
Inward capitals bring know-how, innovative technology and increase in the country economy's productive capacity. Outward investments in other countries sometimes provide opportunities to accessing markets that maintain barriers. Such capitals help enterprises to survive in an increasingly competitive business environment. When the capitals enter the country or go away from, the economic literature captures them as inflows and outflows. In the same country, there is a coexistence of capital inflows with capital outflows. This is a widespread phenomenon in the developed world and a natural outcome of increasing global financial integration. A similar situation can be expected to prevail in developing countries. As theirs incomes and wealth increase the dependence of growth on foreign capital declines, United Nations Conference on Trade and Development (UNTACD, 2000).

Capitals can also be public, from government and official institutions, or private from individuals and particulars, enterprises and multinational firms. Tadaro (1999) considers multinational enterprises as corporations that conduct and control productive activities in more than one country. Multinational enterprises are seen as corporations with northnorth, north-south or south-south capital links and which have theirs headquarters in another country such as Brazil, Britain, China, France, Germany, India, Indonesia, Japan, Korea, Mexico, Russia, and the United States, among others. Some of these countries are presented on the list of the top 10 contributors to global economic growth from 2010 to 2015, International Monetary Fund (IMF, 2010). These multinational companies also function in other countries both developed and developing.

Many varieties of private capital flows exist: there are domestic private capital, in one hand and foreign direct capital, in other hand. Domestic private capital is from private originally, individual or groups, and usually finance private sector. In the category of foreign direct capital mainly we have foreign direct investment (FDI) and portfolio investment. The distinction between FDI and portfolio investment is fundamentally the acquisition of some degree of management control. Usually, the threshold of 10 percent of total equity is used to distinguish the two components. The portfolio investments do generally not involve a controlling interest. FDI can be defining as investment by large multinational corporations with headquarters in the developed countries. FDI is not simply an international transfer of capital but rather, the extension of enterprise from its home country which involves flows of capital, innovative technologies and entrepreneurial skills to the host economy where they are combined with local factors in the production of goods and services for local and for export markets.

Enterprises usually invest up to the point where marginal efficiency of capital equals the user cost of capital. A rise in the user cost reduces optimal capital stock and investment. Many investors consider political and economic stability, availability of natural resources and a large and growing market as important factors to attract private capital. In a global business environment, the following determinants are preferred to stimulate private investment: a favorable environment with low and stable rates and effective competition policies; low transactions and business costs for labor and trade regulations; entry and exit rules; location and environment regulation; subcontract services to local enterprises; support quality assurance and technical extension to small and medium size enterprises; human capital with diverse modern skills; low cost infrastructure such as efficient communications system and transportation links; merger and acquisition; open policies 
in export activities, for example free trade and free foreign exchange regimes to maximize economies of scale.

In African countries, capital investors face risks because changes in market prices and opportunities cannot be perfectly predicted ex ante. They have little trust in the reliability and fairness of property rights and government enforcement. Investors complain that the rules are unclear and variable over time. The business environment, according to Eifert, Gelb and Ramachandran (2005), and the business practices (such as, business networking) are the nexus of policies, institutions, physical infrastructure, human resources, and geographic features which influence the efficiency with which different private enterprises and industries operate. At the level of private enterprises, the business environment directly influences costs of production. At the industry level, it often relates to market structure and competition. These effects are felt more heavily in traded sectors which are not particularly intensive in natural resources. For example manufacturing, high-value services, than in primary production and extractive resource sectors because the former tends to more intensively require inputs of logistics, infrastructure, and regulation (Collier, 2000). Investment climate constraints to private sector in Africa concern economic freedom related on: telecommunications, electricity, transportation, tax rates, tax administration, customs and trade regulations, workers skills and education, business licensing and operating permits, access to financing, cost of financing, interest rates, economic and regulatory policy uncertainty, macro instability, corruption, crime, theft, disorder, and violence. Economic freedom can be dividing into four variables corresponding on the main pillars of economy: business freedom, financial freedom, trade freedom and investment freedom.

Economic growth can be defined as the increase in production in society over time. It is traditionally measured by the relative increase in real gross domestic product from year to year. It implies a sustained increase in gross domestic product for a long time. Economic growth is also conceived as the positive trend in the nations total output over long term. Fundamentally studies related on economic growth, with exogenous (Solow, 1956) or endogenous (Romer, 1986) factors are based on the accelerator theory of investment which suggests that investment responds to transformations and changes in demand for output (Jorgenson, 1971). Governmental macroeconomic policy can affect private investment by directly impacting domestic demand in goods and services. A non expansionary monetary policy that raises interest rates and/or constrains credit expansion will reduce aggregate demand, which reduces private investment. Demand is also affected by fiscal policy directly through government spending and indirectly through transfer programs.

Is the link between private capital, investment climate and economic growth found to be significant or not? Do private capitals and economic freedom exert positive, neutral or negative effects on economic growth? Do private capitals and investment climate influence positively, negatively or neutralize economic growth? Are private capital and investment climate stimulating economic growth in African countries? The aim of this paper is to analyze how private capital and investment climate contribute to economic growth in African countries. This paper provides empirical evidence on the correlation between private capital, investment climate and economic growth by using a time series analysis, an ARDL bounds testing approach and an error-correction model (ECM) in 
some African countries. The content of this paper is as follow: Section 2 reviews the related literature; section 3 presents the methodology and the data sources. Section 4 presents and discusses the results; and the last section concludes.

\section{Literature Review}

Recent theoretical and empirical literatures have highlighted the role play by, first, the private capital on the economic growth and, second, investment climate on the economic growth in African countries. But a few literatures have analyzed the relationship between private capitals, investment climate and economic growth. It is argue that private investment, in a context of doing and facilitating business, has become one of the major channels to access to innovative technologies, to increase international trade and to promote economic growth. Some macroeconomic policies have stimulated private investments (Ndikumana, 2005). Governments have potentially powerful channels to stimulate and to accelerate private investments. Particularly, a domestic demand for goods and services stimulus and public investment expansion produce large profits in private investment process.

There are important empirical and policy reasons for why private capital and investment climate should be at the center of the debate on how to promote economic growth and increase employment. The empirical literature has identified public and private investments as the most robust determinants of economic growth (Levine and Renelt, 1992), especially equipments investments (De Long and Summers, 1991). Both private investment and public investment are main determinants of cross-country differences in long-run economic growth. This empirical relationship between investment and growth has led observers to identify low investment as one of the leading causes of the slow growth in developing countries in general and in African countries in particular (Greene and Villanueva, 1991; Collier and Gunning, 1999).

Beyond the relationship between private investments, the concern for private capital has been in terms of its effects on economic growth. Among the authors who have significantly contributed to the related analysis in Africa, we can cite: De Long and Summers (1991), Oshikoya (1994), Ghura (1997), Beddies (1999), Mlambo and Oshikoya (1999), Devarajan, Easterly and Pack (1999), Ghura and Goodwin (2000), HernandezCata (2000), Beck, Demirguc-Kunt and Levine (2003). Khan and Reinhart (1990) have previously analyzed the relationship between private investment and economic growth in some developing countries.

Willmore (1986) argues that foreign direct investment have a beneficial effect on economic growth because foreign enterprises are more efficient than their local competitors. The author tests this hypothesis on a sample of 282 pairs of enterprises belonging to 80 industries, and finds out that the ratio of added value to output is higher for foreign industries than for their domestic competitors. Blomstrom and Wolff (1989) investigate the productivity spillover channel from foreign direct investment to economic growth. They observe that labor productivity, as well as the domestic production growth rate, have significantly benefited from positive spillovers from foreign direct investment. Borensztein et al. (1998) have investigated the impact of foreign direct investment on economic growth. Their main intuition was that foreign direct investment can play a 
major role in the process of technology diffusion and growth in developing countries. They consider, particularly, the foreign direct investment by multinational enterprises to be a key channel for the access to advanced technologies by developing countries. They used a model of endogenous growth (Romer, 1986; Lucas, 1988) in which the rate of technological progress is the major determinant of the long-term growth rate of income, and performed a cross-country regression. Adams (2009) also analyses how foreign direct investments help to promote economic growth in African countries.

In supporting the various recent endogenous growth theories, Borensztein et al. (1998) highlight the important role play by human capital. Indeed, empirical results suggest that foreign direct investment is an important vehicle for the transfer of innovative technology, contributing relatively more to economic growth than domestic investment. However, the higher productivity of foreign direct investment holds only when the host country has a minimum threshold of human capital. Thus, foreign direct investment contributes to economic growth only when a sufficient absorptive capability of the advanced technologies is available in the host country.

However, cross-country regressions may not be well-suited for economic growth empirics. As emphasized by Levine and Renelt (1992), a lot of conceptual and statistical problems plague cross-country investigations. To begin with, regression analysis presupposes that observations are drawn from a distinct population, which goes against the basic intuition that very different countries may not be comparable. Owusu and Odhiambo (2014) examine the relationship between stock market development and sustainable economic growth using the case of Ghana. The study employs the recently developed ARDL-bounds testing approach and multidimensional stock market development proxies to examine this linkage. The authors find that in the long run, stock market developments and capital account liberalization policies have no positive effect on economic growth.

There is a large body of literature related on the business environment (Eifert, Gelb and Ramachandran, 2005) and linking improvements in the investment climate with economic growth (World Bank, 2005; Knack and Keefer, 1995; Dollar et al., 2003a; Dollar et al., 2003b; Aterido and Hallward-Driemeier, 2008; Escribano and Guasch, 2005). Many studies related on doing business and particularly the World Development Report of 2005 cites a number of cross-country researches that have used broad proxies for the investment climate and demonstrate a link between a good investment climate and economic growth. Using the World Bank's Investment Climate Surveys, this report also highlights improved performance of enterprises in some states and provinces in Asia where there were better investment climates (World Bank, 2005). Knack and Keefer (1995) show a strong link between one key aspect of the investment climate, property rights, on the one hand and investment and economic growth on the other.

There are two main criticisms of this literature. Some authors criticize the measurements used to support claim for a link between improvements in the investment climate and economic growth (Commander and Tinn, 2007; IEG, 2008). Most studies that demonstrate such a link harbor some reservations about using broad proxies to measure the investment climate and are sceptical about the usefulness of broad crosscountry comparisons (World Bank, 2005; Knack and Keefer, 1995; Dollar et al., 2003a; Dollar et al., 2003b). Altenburg and Drachenfels (2006) challenge the assumption that 
regulatory reform is the key to economic growth. Ikejiaku and Mordi (2010) argue that Africa's low economic growth rate and poor economic development are results of unfavorable business investment climate. These authors conclude that there is the need to address these militating factors in order to provide congenial atmosphere that will attract both, domestic and foreign, north-south and south-south investments in Africa.

Previous theoretical and empirical studies of the role of institutions in economic growth (North, 1990) measure institutional quality by the rule of law index (Keefer and Knack, 1994; Sachs and Warner, 1997), the risk of expropriation (Acemoglu, Johnson and Robinson, 2001), government repudiation of contracts (Keefer and Knack, 1995; Sachs and Warner, 1997), bureaucratic quality (Keefer and Knack, 1995; Sachs and Warner, 1997), incidence of corruption (Mauro, 1995), and constraints on the executive (Glaeser et al., 2004). To analyse whether investment climate can explain economic growth independent of these other institutional variables, some other variables can be included in the estimated equations along with the business environment measure, and standard control variables used in growth regressions such as inflation, government consumption and openness.

Governmental institutions in Africa, which reform and secure property rights (Adams, 2010), guarantee the political stability, free political parties, convertibility of the currency, laws on the bankruptcy of the companies and monitoring of the markets, liberalization of the prices, privatization of the public enterprises, encouragement of the private sector, reorganization of the financial system, liberalization of capital account, and weaken the corruption, promote a good capital investment climate. From the above literature cited, we suppose also that in African countries good institutions play a crucial role to attract domestic private investment and foreign direct investors for economic growth. In our study we combine times series analysis and the ARDL-bounds testing approach for more significantly explain our empirical results.

\section{Methodology: Econometric Model and Data}

\subsection{Econometric model}

From the above literature and the modified and augmented version of Naceur et al. (2008), Bekaert et al. (2005) and, Owusu and Odhiambo (2014), in this paper, we specify four modified models for economic growth. We capture investment climate using economic freedom dynamics in Africa. All the models include public investment $(G)$, trade openness $(\mathrm{TO})$, real effective exchange rate $(\mathrm{R})$, gross saving $(\mathrm{S})$ and private capital flow $(\mathrm{K})$ as independent variables. In addition to the above independent variables, the fourth proxies for freedom economic development indicators, i.e. business freedom $(\mathrm{BF})$, financial freedom $(\mathrm{FF})$, trade freedom $(\mathrm{TF})$ and investment freedom (IF), have been included independently in the fourth equations to capture the effect of investment climate on economic growth. The equations are specified as follows:

$$
\ln Y_{t}=\alpha_{1}+\alpha_{2} \ln G_{t}+\alpha_{3} \ln T O_{t}+\alpha_{4} \ln R_{t}+\alpha_{5} S_{t}+\alpha_{6} K_{t}+\alpha_{7} B F+\varepsilon_{1 t}
$$




$$
\begin{aligned}
& \ln Y_{t}=\delta_{1}+\delta_{2} \ln G_{t}+\delta_{3} \ln T O_{t}+\delta_{4} \ln R_{t}+\delta_{5} S_{t}+\delta_{6} K_{t}+\delta_{7} F F+\varepsilon_{2 t} \\
& \ln Y_{t}=\kappa_{1}+\kappa_{2} \ln G_{t}+\kappa_{3} \ln T O_{t}+\kappa_{4} \ln R_{t}+\kappa_{5} S_{t}+\kappa_{6} K_{t}+\kappa_{7} I F+\varepsilon_{3 t} \\
& \ln Y_{t}=\lambda_{1}+\lambda_{2} \ln G_{t}+\lambda_{3} \ln T O_{t}+\lambda_{4} \ln R_{t}+\lambda_{5} S_{t}+\lambda_{6} K_{t}+\lambda_{7} T F+\varepsilon_{4 t}
\end{aligned}
$$

Where: ${ }_{t}$, the dependent variable, represents the real gross domestic product per capita at time $t ; \alpha_{1}, \delta_{1}, \kappa_{1}$ and $\lambda_{1}$ are the constant parameters; $\alpha_{i}, \delta_{i}, \kappa_{i}$ and $\lambda_{i}$ for $2 \leq i \leq 7$, are the associate coefficients to each variable respectively in the first, second, third and fourth equation; the ${ }^{\varepsilon_{t}}$, s are the white noise error terms; and $\ln$ is the natural logarithm operator.

The methodology used in this study is based on the autoregressive distributed lags (ARDL)-bounds testing approach, which was developed by Pesaran et al. (2001). It has three advantages in comparison with other previous and traditional cointegration methods. The first one is that this approach does not need that all the variables under study must be integrated in the same order. It can be applied when the underlying variables are integrated in order one, order zero or fractionally integrated. The second advantage is that the ARDL test is relatively more efficient in the case of small and finite sample data sizes. Thirdly, the test is relatively more efficient in small or finite sample data sizes as it is the case in our research. The procedure will however crash in the presence of an integrated series of an order upper than one - I(2) and greater for example.

The autoregressive distributed lags (ARDL) technique involves two steps. In the first step, the ARDL model of interest is estimated by using the ordinary least square (OLS) in order to test for the existence of a long-run relationship among the relevant variables. In order to test the null hypothesis of no long-run relationship among the variables in the equation, a Wald F-test for the joint significance of the lagged levels of the variables is performed. If the F-statistic is above the upper critical value, the null hypothesis of no long-run relationship can be rejected, irrespective of the orders of integration for the time series. Conversely, if the test statistic falls below the lower critical value, then the null hypothesis cannot be rejected. However, if the statistic falls between the upper and the lower critical values, then the result is inconclusive. Once the long-run relationship or cointegration has been established, the second step involves the estimation of the longrun coefficients representing the optimum order of the variables after selection by AIC or SBC. Thereafter, a general error-correction model (ECM) can be formulated as follows: 


$$
\begin{aligned}
\Delta \ln Y_{t}= & a_{0}+\sigma_{1} \ln Y_{t-1}+\sigma_{2} \ln G_{t-1}+\sigma_{3} \ln T O_{t-1}+\sigma_{4} \ln R_{t-1}+\sigma_{5} \ln S_{t-1}+\sigma_{6} \ln K_{t-1} \\
& +\sigma_{7} \ln B F_{t-1}+\sum_{i=1}^{p} \alpha_{i} \Delta \ln Y_{t-i}+\sum_{j=1}^{q} \varsigma_{j} \Delta \ln G_{t-j}+\sum_{k=1}^{q} \lambda_{k} \Delta \ln T O_{t-k}+\sum_{m=1}^{q} \xi_{m} \Delta \ln R_{t-m} \\
& +\sum_{n=1}^{q} \kappa_{n} \Delta S_{t-n}+\sum_{l=1}^{q} \theta_{l} \Delta K_{t-l}+\sum_{l=1}^{q} \omega_{l} \Delta B F_{t-l}+v_{1 t}
\end{aligned}
$$

$\Delta \ln Y_{t}=a_{1}+\delta_{1} \ln Y_{t-1}+\delta_{2} \ln G_{t-1}+\delta_{3} \ln T O_{t-1}+\delta_{4} \ln R_{t-1}+\delta_{5} \ln S_{t-1}+\delta_{6} \ln K_{t-1}$

$$
\begin{aligned}
& +\delta_{7} \ln B F_{t-1}+\sum_{i=1}^{p} \alpha_{i} \Delta \ln Y_{t-i}+\sum_{j=1}^{q} \varsigma_{j} \Delta \ln G_{t-j}+\sum_{k=1}^{q} \lambda_{k} \Delta \ln T O_{t-k}+\sum_{m=1}^{q} \xi_{m} \Delta \ln R_{t-m} \\
& +\sum_{n=1}^{q} \kappa_{n} \Delta S_{t-n}+\sum_{l=1}^{q} \theta_{l} \Delta K_{t-l}+\sum_{l=1}^{q} \omega_{l} \Delta F F_{t-l}+v_{2 t}
\end{aligned}
$$

$\Delta \ln Y_{t}=a_{2}+o_{1} \ln Y_{t-1}+o_{2} \ln G_{t-1}+o_{3} \ln T O_{t-1}+o_{4} \ln R_{t-1}+o_{5} \ln S_{t-1}+o_{6} \ln K_{t-1}$

$$
\begin{aligned}
& +O_{7} \ln B F_{t-1}+\sum_{i=1}^{p} \alpha_{i} \Delta \ln Y_{t-i}+\sum_{j=1}^{q} \varsigma_{j} \Delta \ln G_{t-j}+\sum_{k=1}^{q} \lambda_{k} \Delta \ln T O_{t-k}+\sum_{m=1}^{q} \xi_{m} \Delta \ln R_{t-m} \\
& +\sum_{n=1}^{q} \kappa_{n} \Delta S_{t-n}+\sum_{l=1}^{q} \theta_{l} \Delta K_{t-l}+\sum_{l=1}^{q} \omega_{l} \Delta I F_{t-l}+v_{3 t}
\end{aligned}
$$

$\Delta \ln Y_{t}=a_{3}+\rho_{1} \ln Y_{t-1}+\rho_{2} \ln G_{t-1}+\rho_{3} \ln T O_{t-1}+\rho_{4} \ln R_{t-1}+\rho_{5} \ln S_{t-1}+\rho_{6} \ln K_{t-1}$

$$
\begin{aligned}
& +\rho_{7} \ln B F_{t-1}+\sum_{i=1}^{p} \alpha_{i} \Delta \ln Y_{t-i}+\sum_{j=1}^{q} \varsigma_{j} \Delta \ln G_{t-j}+\sum_{k=1}^{q} \lambda_{k} \Delta \ln T O_{t-k}+\sum_{m=1}^{q} \xi_{m} \Delta \ln R_{t-m} \\
& +\sum_{n=1}^{q} \kappa_{n} \Delta S_{t-n}+\sum_{l=1}^{q} \theta_{l} \Delta K_{t-l}+\sum_{l=1}^{q} \omega_{l} \Delta T F_{t-l}+v_{4 t}
\end{aligned}
$$

where $\sigma_{i}, \delta_{i}, O_{i}$ and $\rho_{i}$ represent the long-run multipliers corresponding to long-run relationships; $a_{0}, a_{1}, a_{2}$ and ${ }^{a_{3}}$ represent drifts; and the ${ }^{v_{*}}$,s represent white noise errors for each equation. The short-run effects in the above equations are captured by the coefficients of the first differenced variables in the unrestricted error-correction model (UECM model). Note that, the existence of a long-term relationship does not necessarily imply that the estimated coefficients are stable. This suggests that there is a need to perform a series of tests diagnoses on the model established (Bahmani-Oskooee and Brooks, 1999). This involves testing of the residuals, as well as stability tests-to ensure that the estimated model is statistically robust. To test the existence of a long-run relationship for each of the above equations, one conducts an F-test for a joint significance of the coefficient of the lagged levels, by using the OLS. The general UECM is tested downwards sequentially, by dropping the statistically non-significant first differenced variables for each of the equations-to arrive at a 'good-ness-of-fit' model- 
using a general-to-specific strategy (Poon, 2010). Once the cointegration relationships have been established, the long-run elasticities or coefficients can then be generated from UECM, by using the estimated coefficients of the one-lagged independent variables, multiplied by a negative sign, and divided by the estimated coefficient of the one-lagged dependent variable (Bardsen, 1989).

\subsection{Data}

Data are from World Development Indicator 2012 for dependent variable, gross domestic product (GDP) per capita and independent variables: gross saving, export, import, real effective exchange rate, public investment, and private capitals. These data are available from 1960 to 2011. Data related to investment climate captured here by economic freedom are from Freedom Heritage declined in four variables: business freedom, financial freedom, investment freedom, and trade freedom. These data are available from 1995 to 2014. Five African countries are under study: Cameroon, Côte d'Ivoire, Tunisia, South Africa and Zambia.

\section{Empirical Results}

Before running the causality test, the variables must be tested for stationarity. For this purpose, in this current study we use the conventional Augmented DickeyFuller (ADF) tests. The ARDL bounds test is based on the assumption that the variables are $\mathrm{I}(0)$ or $\mathrm{I}(1)$. The determination of the order of integration of all variables is another important issue. The objective is to ensure that the variables are not $\mathrm{I}(2)$ so as to avoid spurious results. In the presence of variables integrated in order two, one cannot interpret the values of the F statistics provided by Pesaran et al. (2001).

Table 1: Unit root tests

\begin{tabular}{|c|c|c|c|c|c|c|}
\hline Variables & & Cameroon & Côte d'Ivoire & Tunisia & South Africa & Zambia \\
\hline & $\ln Y$ & $\begin{array}{l}-1.53 \\
\left(-5.08^{* * *}\right)\end{array}$ & $\begin{array}{l}-2.62 \\
(-5.43 * * *)\end{array}$ & $\begin{array}{l}-2.26 \\
(-7.57 * * * a)\end{array}$ & $\begin{array}{l}-2.75 \\
(-3.98 * *)\end{array}$ & $\begin{array}{l}-0.18 \\
\left(-6.83^{* * *}\right)\end{array}$ \\
\hline & $\ln G$ & $\begin{array}{l}-1.61 \\
(-5.59 * * *)\end{array}$ & $\begin{array}{l}-2.38 \\
(-4.84 * * * a)\end{array}$ & $\begin{array}{l}-2.57 \\
(-4.28 * *) \\
\end{array}$ & $\begin{array}{l}-3.05 \\
(-5.32 * * * a)\end{array}$ & $\begin{array}{l}-1.55 \\
(-5.82 * * *)\end{array}$ \\
\hline & $\ln \mathrm{R}$ & $\begin{array}{l}-1.88 \\
\left(-5.11^{* * *}\right)\end{array}$ & $\begin{array}{l}-2.48 \\
(-5.51 * * *)\end{array}$ & $\begin{array}{l}-2.34 \\
(-3.42 *) \\
\end{array}$ & $\begin{array}{l}3.57^{*} b \\
\left(-4.72^{* * *}\right)\end{array}$ & $\begin{array}{l}-2.67 \\
(-4.47 * * * b)\end{array}$ \\
\hline & $\ln T O$ & $\begin{array}{l}-1.69 \\
\left(-5.66^{* * *}\right)\end{array}$ & $\begin{array}{l}-1.64 \\
(-9.63 * * * a)\end{array}$ & $\begin{array}{l}-1.08 \\
(-6.71 * * * a)\end{array}$ & $\begin{array}{l}-1.84 \\
(-5.23 * * *)\end{array}$ & $\begin{array}{l}-0.47 \\
(-2.09)\end{array}$ \\
\hline & $S$ & $\begin{array}{l}-0.73 \\
\left(-4.83^{* * *}\right)\end{array}$ & $\begin{array}{l}-1.14 \\
\left(-5.67^{* * *}\right)\end{array}$ & $\begin{array}{l}-1.39 \\
(-5.65 * * *)\end{array}$ & $\begin{array}{l}-0.91 \\
\left(-4.60^{* * *}\right)\end{array}$ & $\begin{array}{l}-0.02 \\
(-6.69 * * * b)\end{array}$ \\
\hline & K & $\begin{array}{l}-2.38 \\
(-10.55 * * *)\end{array}$ & $-3.25 * b$ & $4.29 * * *$ & $-5.45 * * * b$ & $-4.22 * * b$ \\
\hline & $B F$ & $\begin{array}{l}-1.79 \\
\left(-3.96^{* *}\right) \\
\end{array}$ & $\begin{array}{l}-3.15 \\
(-4.57 * *) \\
\end{array}$ & & $\begin{array}{l}-2.70 \\
\left(-4.55^{* * b}\right)\end{array}$ & $\begin{array}{l}2.40 \\
(-2.97) \\
\end{array}$ \\
\hline & $F F$ & $-3.85 * * b$ & $\begin{array}{l}-1.18 \\
\left(-4.16^{* *}\right) \\
\end{array}$ & $\begin{array}{l}-1.85 \\
\left(-4.34^{* *}\right) \\
\end{array}$ & $-4.29 * * a$ & $\begin{array}{l}-1.52 \\
(-4.30 * *)\end{array}$ \\
\hline & $I F$ & $\begin{array}{l}-2.06 \\
(-2.83) \\
\end{array}$ & $\begin{array}{l}-1.38 \\
(-2.02) \\
\end{array}$ & $\begin{array}{l}-3.15 \\
(-5.21 * * *)\end{array}$ & $\begin{array}{l}-1.20 \\
(-3.27)\end{array}$ & $\begin{array}{l}-1.02 \\
(-4.05 * *)\end{array}$ \\
\hline & $T F$ & $\begin{array}{l}-2.00 \\
\left(-4.70^{* * *}\right)\end{array}$ & $\begin{array}{l}-2.21 \\
(-6.32 * * * b)\end{array}$ & $\begin{array}{l}-1.26 \\
(-1.78)\end{array}$ & $\begin{array}{l}-2.46 \\
(-5.58 * * *)\end{array}$ & $\begin{array}{l}-1.88 \\
(-5.02 * * *)\end{array}$ \\
\hline \multicolumn{7}{|c|}{$\begin{array}{l}\text { The corresponding tests for the first differences of each variable are shown in parentheses. *, ** and *** respectively } \\
\text { indicates the significance at 10\%, 5\% and 1\% level using the Mackinnon (1991) critical values. a (resp. b) } \\
\text { indicates a model with only a significance drift (resp. linear trend and drift) }\end{array}$} \\
\hline
\end{tabular}


The ADF unit root test results are summarized in the Table 1. One important remark here is that in this work all the variables are not integrated in the same order. Thus the bounds tests cointegration procedure is therefore appropriate. Another important observation is that the variables which are integrated in an order upper to one, will remove the corresponding equation for the corresponding country. And if these variable are business freedom (BF), financial freedom (FF), investment freedom (IF) or trade freedom (TF) we stop the estimation procedure for this country at the corresponding equation.

Table 2: Bound tests approach on functions

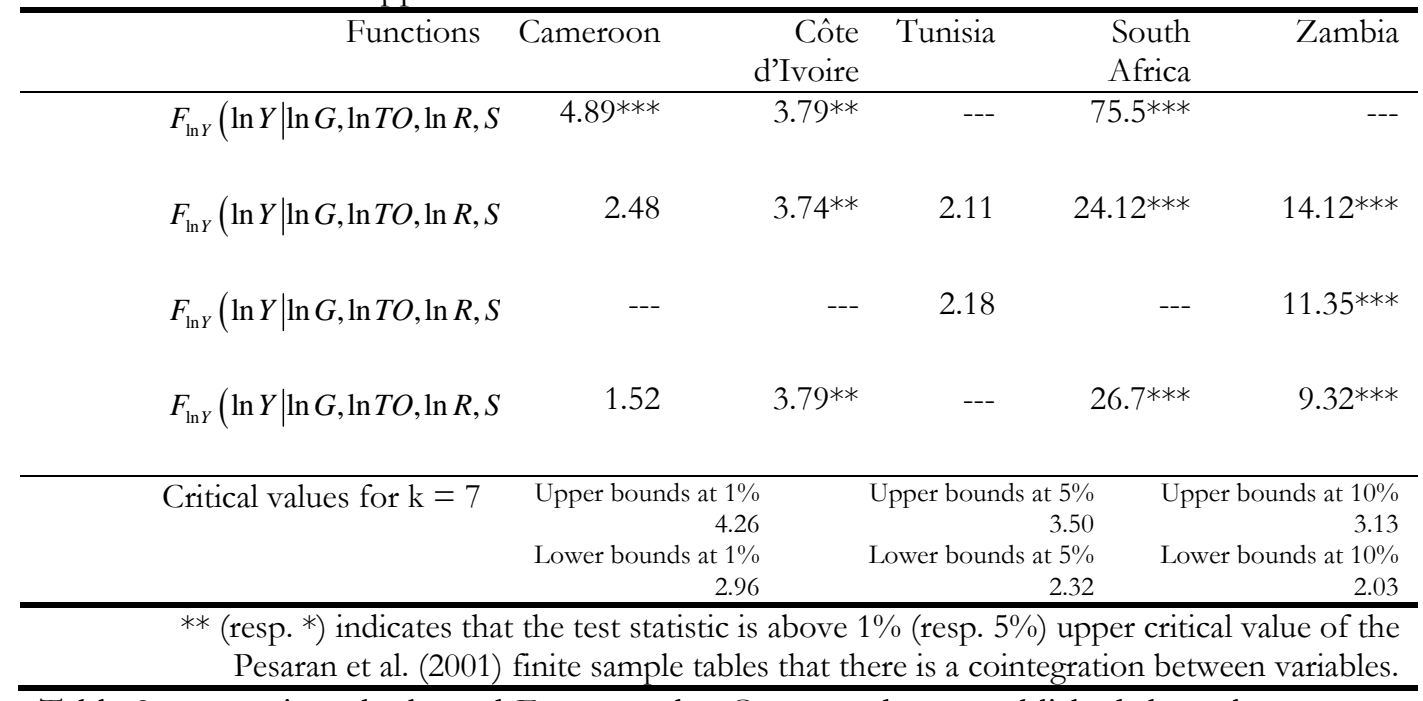

Table 2 summarizes the bound F-test results. Once, we have established that a long run relationship exists between the variables. This implies that there is a long run

Table 3a: Economic growth and business freedom - ARDL $(1,0,0,0,0,0,0)$ long run estimates

\begin{tabular}{|c|c|c|c|c|c|}
\hline Variables & Cameroon & Côte d'Ivoire & Tunisia & South Africa & Zambia \\
\hline \multirow[t]{2}{*}{ Constant } & $-1.74^{*}$ & 4.40 & - & $-2.50 * * *$ & - \\
\hline & & & -- & & -- \\
\hline \multirow[t]{2}{*}{$\ln G$} & $0.16^{* *}$ & 0.03 & - & $0.18^{* *}$ & - \\
\hline & & & -- & & -- \\
\hline \multirow[t]{2}{*}{$\ln R$} & $0.13^{*}$ & 0.09 & - & $-0.04 * *$ & - \\
\hline & & & -- & & -- \\
\hline \multirow[t]{2}{*}{$\ln \mathrm{TO}$} & $0.08^{* * *}$ & -0.14 & - & $0.15^{* * *}$ & - \\
\hline & & & -- & & -- \\
\hline \multirow[t]{2}{*}{ S } & $-5.84 \mathrm{E}-12$ & $1.62 \mathrm{E}-11$ & - & 7.99E-13** & - \\
\hline & & & -- & & -- \\
\hline \multirow[t]{2}{*}{ K } & 0.00 & 0.02 & - & 0.00 & - \\
\hline & & & -- & & -- \\
\hline \multirow[t]{2}{*}{$\mathrm{BF}$} & -0.01 & 0.08 & - & 0.04 & - \\
\hline & & & -- & & -- \\
\hline
\end{tabular}


cointegration relationship among the variables in some equations in Cameroon, Côte d'Ivoire, South Africa and Zambia. Equations were estimated using the appropriate order of the ARDL specification. The results obtained are reported in the Tables $3 \mathrm{a}, 3 \mathrm{~b}$, $3 \mathrm{c}$ and $3 \mathrm{~d}$.

Table 3a indicates that in Cameroun, in Côte d'Ivoire and in South Africa there is a relationship between dependent variable and independent variables. But we note a statistically insignificant null effect of private capital and a negative (respectively positive) effect of business freedom on economic growth $(\ln Y)$ in the long run in Cameroon respectively in South Africa. In Cameroon and in South Africa, public investment and real effective exchange rate respectively are significant.

Table 3b: Economic growth and financial freedom - ARDL $(1,0,0,0,0,0,0)$ long run estimates

\begin{tabular}{|c|c|c|c|c|c|}
\hline Variables & Cameroon & Côte d'Ivoire & Tunisia & South Africa & Zambia \\
\hline Constant & --- & $5.83^{*}$ & -- & $-2.14^{* *}$ & -0.21 \\
\hline $\ln G$ & --- & -0.03 & -- & $0.13^{*}$ & 0.12 \\
\hline $\ln R$ & --- & 0.17 & $\begin{array}{l}-- \\
-\end{array}$ & -0.02 & -0.04 \\
\hline $\ln \mathrm{TO}$ & --- & $-0.15^{*}$ & $\begin{array}{c}-- \\
-\end{array}$ & $0.16^{* * *}$ & --- \\
\hline S & --- & $1.31 \mathrm{E}-11$ & $\begin{array}{l}-- \\
-\end{array}$ & 7.14E-13* & 2.64E-11 \\
\hline K & --- & 0.024 & $\begin{array}{l}-- \\
-\end{array}$ & $-4.52 \mathrm{E}-05$ & -0.00 \\
\hline $\mathrm{FF}$ & --- & -0.083 & $\begin{array}{l}-- \\
-\end{array}$ & -0.01 & -0.07 \\
\hline
\end{tabular}

Table $3 \mathrm{~b}$ indicates that in Côte d'Ivoire, in South Africa and in Zambia there is a relationship between dependent variable and independent variables. We note a statistically insignificant positive (respectively negative) effect of private capital and a negative (respectively negative) effect of business freedom on economic growth ( $\ln Y$ ) in the long run in Côte d'Ivoire (respectively in South Africa and in Zambia). In the case of Côte d'Ivoire and South Africa, trade openness is significant.

Table 3c: Economic growth and investment freedom - ARDL $(1,0,0,0,0,0,0)$ long run estimates

\begin{tabular}{|c|c|c|c|c|c|}
\hline Variables & Cameroon & Côte d'Ivoire & Tunisia & South Africa & Zambia \\
\hline Constant & $\overline{---}$ & $\overline{---}$ & -- & -- & -0.53 \\
\hline $\ln G$ & --- & --- & --- & --- & 0.13 \\
\hline $\ln R$ & --- & --- & --- & --- & 0.03 \\
\hline $\ln \mathrm{TO}$ & --- & --- & --- & --- & --- \\
\hline S & --- & -- & --- & --- & $1.05 \mathrm{E}-11$ \\
\hline K & --- & -- & --- & --- & -0.000 \\
\hline IF & --- & -- & --- & --- & -0.07 \\
\hline
\end{tabular}


In the Table $3 c$ only Zambia has dependent variable in relationship with the independent variables. Statistically the effects of private capital and investment freedom are insignificant.

Table 3d: Economic growth and trade freedom - ARDL $(1,0,0,0,0,0,0)$ long run estimates

\begin{tabular}{|c|c|c|c|c|c|}
\hline Variables & Cameroon & Côte d'Ivoire & Tunisia & South Africa & Zambia \\
\hline Constant & --- & 3.51 & --- & $-1.91 * *$ & -2.66 \\
\hline $\ln G$ & --- & -0.02 & --- & 0.11 & 0.21 \\
\hline $\ln R$ & --- & 0.13 & --- & -0.02 & -0.04 \\
\hline $\ln \mathrm{T}$ & --- & -0.07 & --- & $0.17^{*}$ & --- \\
\hline \multicolumn{6}{|l|}{$\mathrm{O}$} \\
\hline S & --- & $1.89 \mathrm{E}-11$ & --- & 7.52E-13* & $\begin{array}{r}1.81 \\
\text { E-11 }\end{array}$ \\
\hline K & --- & 0.02 & --- & 8.93E-05 & -0.00 \\
\hline TF & --- & -0.09 & --- & 0.00 & 0.07 \\
\hline
\end{tabular}

Table $3 \mathrm{~d}$ shows that there is an insignificant relationship between the dependent and the independent variables. This paper has employed four proxies of economic freedom namely business freedom, financial freedom, investment freedom and trade freedom. The results of this analysis suggest that private capital and investment climate have an insignificant effect on the economic growth in Cameroon, Côte d'Ivoire, South Africa and Zambia in long run.

The results of the short-run dynamics when the proxies are combined, emanating from the long-run relationships are shown in Table 4.

Table 4: Economic growth and economic freedom - short run estimates

\begin{tabular}{|c|c|c|c|c|c|}
\hline Variables & Cameroon & Côte d'Ivoire & Tunisia & South Africa & Zambia \\
\hline $\begin{array}{l}\text { selected } \\
\text { equation }\end{array}$ & (2) & (1) & & (4) & (3) \\
\hline Constant & $0.73^{* *}$ & $-0.01 * * *$ & --- & -0.002 & 0.50 \\
\hline$D \ln G$ & 0.07 & $0.18^{* *}$ & --- & 0.34 & 1.21 \\
\hline $\mathrm{D} \ln \mathrm{R}$ & 0.04 & $0.17^{*}$ & --- & -0.06 & 0.04 \\
\hline DlnTO & -0.01 & $0.14^{* *}$ & --- & 0.07 & --- \\
\hline DS & $5.52 \mathrm{E}-12$ & $7.00 \mathrm{E}-12$ & --- & $1.65 \mathrm{E}-12$ & $2.07 \mathrm{E}-11$ \\
\hline $\mathrm{DK}$ & $-4.81 \mathrm{E}-06$ & $0.01 * *$ & --- & -0.00 & 0.006 \\
\hline $\mathrm{D}$ (Freedom) & 0.01 & $-0.11 *$ & --- & 0.036 & -0.02 \\
\hline $\mathrm{D} \ln \mathrm{Y}(-1)$ & $0.28^{*}$ & $0.56 * * *$ & --- & 0.25 & 0.62 \\
\hline $\operatorname{ECM}(-1)$ & $-0.11 * *$ & $-0.72 * *$ & --- & -0.0006 & -0.09 \\
\hline Adjusted $\mathrm{R}^{2}$ & 0.91 & 0.93 & & $\begin{array}{r}0.9 \\
3\end{array}$ & 0.87 \\
\hline Durbin & 1.99 & 2.35 & & 3.2 & 1.93 \\
\hline Watson & & & & 2 & \\
\hline F-stat & $16.16^{* *}$ & $24 * * *$ & & $19.8^{* *}$ & $9.84 *$ \\
\hline \multicolumn{6}{|c|}{$\begin{array}{l}\text { *, ** and *** respectively indicates the significance at } 10 \%, 5 \% \text { and } 1 \% \text { level. } D \text { is the difference operator; } \\
\text { Dependent variable is DlnYt.D(Freedom) respectively represent BF, FF, IF and TF for the equation (1), (2), } \\
\text { (3) and (4) }\end{array}$} \\
\hline
\end{tabular}


In the Table 4, when the proxies are combined, private capital has respectively negative, positive, null and positive effect on economic growth in Cameroon, in Côte d'Ivoire, in South Africa and in Zambia. The independent variable freedom has respectively positive, negative, positive and negative effect on economic growth in Cameroon, in Côte d'Ivoire, in South Africa and in Zambia. In the case of Côte-d'Ivoire the coefficient of private capital and economic freedom is statistically significant. We note the significance at $5 \%$ level of private capital and at 1\% level of economic freedom. The coefficient ECM $(-1)$ is found to be very small in magnitude. The ECM is statistically significant at the 5\% level in the case of Cameroon and Côte d'Ivoire. Adjusted R-square is respectively 0.91, 0.93, 0.93 and 0.87 for Cameroon, Côte d'Ivoire, South Africa and Zambia.

Considering the Case of Côte d'Ivoire, adjusted R-square shows that $93 \%$ of variation in gross domestic product (our proxy for economic growth) is caused by variations in the explanatory variables (private capital, exchange rate public investment, economic freedom, trade openness and total domestic savings). The Durbin-Watson statistics is 2.35 which shows that autocorrelation doesn't exist in the regression equation. The Fstat shows that the relationship between private capital, investment climate and GDP is statistically significant to warrant the undue emphasis that private capital can actually fill the investment gap that will give the desired rate of economic growth.

\section{Conclusion}

The aims of this paper were to analyze how private capital and investment climate contribute to economic growth in African countries using times series and ARDLbounds testing approach. We also employ error-correction model (ECM) to examine the linkage. We find that there is a relationship between private capital, investment climate and economic growth in Côte d'Ivoire. From the work of Borenztein et al. (1998) a strong and significant relationship was established between foreign direct investment and economic growth. This study has also established a significant relationship between private capital, investment climate and economic growth in some African countries.

African countries are nowadays faced with great challenges related on economic freedom such as promoting peace, fighting again corruption, and boosting economic prosperity, political stability and good governance. The African leaders, stakeholders and policy makers should do this by themselves. All participants should play theirs full part in sustaining investment climate and in the global economy perspectives. Through this, African countries should display opportunities and assure private national and foreign investors good and high return in their investments from and on the continent. The main policy implication of this paper is the need to ensure a functioning and enduring investment climate, captured by economic freedom, in order to encourage private investment for positive economic growth in African countries. 


\section{References}

Acemoglu, D., Johnson, S. and Robinson, J. (2001), The Colonial Origins of Comparative Development, American Economic Review, Vol. 91, N 5, pp. 1369-1401.

Adams, S. (2010), Intellectual Property Rights, Investment Climate and FDI in Developing Countries, International Business Research, Vol. 3, N 3, pp. 201-209

Adams, S. (2009), Can foreign direct investment (FDI) help to promote growth in Africa?, African Journal of Business Management, Vol. 3, N5, pp. 178-183.

Altenburg, T. and von Drachenfels, C. (2006), The "New Minimalist Approach" to Private Sector Development: A Critical Assessment, Development Policy Review, Vol. 24, N 4, pp. 397411

Aterido, R. and Hallward-Driemeier, M. (2008), Putting African Employment Growth in a Global Context: Impact of Access to Finance, Infrastructure and Regulations across Firms, Centre for Study of African Economies, Oxford University

Bahmani-Oskooee, M. and Brooks, T. J. (1999), Bilateral J-curve between US and Her Trading Partners, Weltwirtschaftliches Archiv, N 135, pp. 156-65.

Bardsen, G. (1989), Estimation of long-run coefficients in error correction models, Oxford Bulletin of Economics and Statistics, $\mathrm{N}^{\circ}$ 51, pp. 345-50.

Beck, T, Demirguc-Kunt, A. and Levine, R. (2003), The Impact of SMEs on Growth, Development and Poverty: Cross Country Evidence, World Bank Policy Research Working Paper Series, $\mathrm{N}^{\circ} 3178$.

Beddies, C. (1999), Investment, Capital Accumulation and Growth: Some Evidence from Gambia: 1964-1998, IMF Working Paper, N¹999/117.

Bekaert, G., Campbell, R. H. and Lundblad, C. (2005), Does financial liberalization spur growth?, Journal of Financial Economics, $\mathrm{N}^{\circ} 77$, pp. 3-55.

Blomstrom, M. and Wolff, E. M. (1989), Multinational Corporations and Productivity Convergence in Mexico, NBER Working Paper, $\mathrm{N}^{\circ}$ W3141.

Borensztein, E., De Gregorio J., and Lee, J. W. (1998), How Does Foreign Direct Investment Affect Economic Growth? Journal of International Economics, Vol. 45, Nº1, pp. 115-35.

Collier, P. (2000), Africa's Comparative Advantage, in Jalilian, H., Tribe, M. and Weiss, J. (eds), Industrial Development and Policy in Africa, Cheltenham: Edward Elgar.

Collier, P. and Gunning, J. (1999), Explaining African economic performance, Journal of Economic Literature, Vol. 37, N¹, pp. 64-111.

Commander, S., Svejnar, J. and Tinn, J. (2008), Explaining the Performance of Firms and Countries: What Does the Business Environment Play?, Discussion Paper, $N^{\circ} 1(\mathrm{E})-$ 2008.

De Long, B. J. and Summers, L. H. (1991), Equipment investment and economic growth, Quarterly Journal of Economics, Vol. 106, N², pp.445-502.

Devarajan, S., Easterly W., and Pack, H. (1999), Is Investment in Africa Too High or Too Low? Macro and Micro Evidence, Journal of African Economies, Vol. 10, supplement 2, pp. 81108.

Dollar, D., Hallward-Driemeier, M., Anqing, S., Wallsten, S., Wang, S. and Xu, L. (2003a), Improving the Investment Climate in China, World Bank, March.

Dollar, D., Hallward-Driemeier, M., Mengistae, T. (2003b), Investment Climate and Firm Performance in Developing Economies, Development Research Group, World Bank.

Easterly, W. (2005), The '50s: the Big Push, Poverty Traps and Takeoffs in Economic Development, Center for Global Development, Working Paper, $N^{\circ}$ 65, Août.

Eifert, B., Gelb, A. and Ramachandran, V. (2005), Business Environment and Comparative Advantage in Africa: Evidence from the Investment Climate Data, ICA Paper, January 
Escribano, A. and Guasch, J. (2005), Assessing the Impact of the Investment Climate on Productivity Using Firm-Level Data: Methodology and the Cases of Guatemala, Honduras, and Nicaragua, World Bank Policy Research Working Paper, Nº 3621.

Ghura, D. (1997), Private Investment and Endogenous Growth: Evidence from Cameroon, IMF Working Paper, $\mathrm{N}^{\circ}$ 97/165, December.

Ghura, D. and Goodwin, B. (2000), Determinants of private investment: A cross-regional empirical investigation, Applied Economics, N³2, pp.1819-1829.

Glaeser E., La Porta, R. and Lopez-de-Silanes, F. (2004), Do Institutions Cause Growth?. Journal of Economic Growth, No 9, pp. 271-303.

Greene, J. and Villanueva, D. (1991), Private investment in developing countries, IMF Staff Papers, Vol. 38, N¹, pp. 33-58.

Hernandez-Cata, E. (2000), Raising Growth and Investment in Sub-Saharan Africa: What can be done?, Policy Discussion Paper, N PDP/00/4, IMF, Washington, D.C.

IEG (2008), Doing Business: An Independent Evaluation: Taking the Measure of the World Bank-IFC Doing Business Indicators, Independent Evaluation Group, Washington D.C: World Bank

Ikejiaku, B.-V. and Mordi, C. (2010), Weak Business Investment Climate, Poor Economic Growth And Africa's Poor Socio-Economic Development, Journal of Sustainable Development in Africa, Vol. 12, Nº1, pp. 106-123

IMF (2010), World Economic Outlook (WEO) - Recovery, Risk and Rebalancing, October Jorgenson, D. W. (1971), Econometric Studies of Investment Behavior: A Survey. Journal of Economic Literature, Vol. 9, N4, pp. 1111-1147

Khan, M.S. and Reinhart, C. M. (1990), Private Investment and Economic Growth in Developing Countries, World Development, Vol. 18, No 1, pp. 19-27.

Knack, S. and Keefer, P. (1995), Institutions and Economic Performance: Cross-Country Tests Using Alternative Institutional Measures, Economics and Politics, Vol. 7, N. 3, pp. $207-$ 227.

Levine, R. and Renelt, D. (1992), A Sensitivity Analysis of Cross Country Growth Regressions, American Economic Review, Vol. 82, N4, pp. 942-63.

Lucas, R. E. (1988), On the Mechanics of Economic Development, Journal of Monetary Economics, Vol. 22, $\mathrm{N}^{\circ} 1$, pp. 3-42.

Mauro, P. (1995), Corruption and Growth, The Quarterly Journal of Economics, N 60, pp. 681-713.

Mlambo, K. and Oshikoya, T. W. (1999), Macroeconomic Factors and Investment in Africa, Journal of African Economies, Vol. 10, supplement 2, pp. 12-47

Naceur, S. B., Ghazouani, S. and Omran, M. (2008), Does Stock Market Liberalization Spur Financial and Economic Development in MENA region?, Journal of Comparative Economics, $\mathrm{N}^{\circ} 36$, pp. 673-93.

Ndikumana, L. (2005), Can Macroeconomic Policy Stimulate Private Investment in South Africa? New Insights from Aggregate and Manufacturing Sector-Level Evidence, Working Paper, N²005-14, Economics Department, University of Massachusetts - Amherst

North, D. C. (1990), Institutions, Institutional Change and Economic Performance, Cambridge, Cambridge University Press.

Oshikoya, T.W. (1994), Macroeconomic Determinants of Domestic Private Investment in Africa: An Empirical Analysis, Economic Development and Cultural Change, Vol. 42, N 3, pp. 573596.

Pesaran, M. H., Shin, Y. and Smith, R. J. (2001), Bounds testing approaches to the analysis of level relationships, Journal of Applied Econometrics, $\mathrm{N}^{\circ} 16$, pp.289-326.

Romer, P. (1986), Increasing Returns and Long-Run Growth, Journal of Political Economy, Vol. 94, $\mathrm{N}^{\circ}$ 5, pp. 1002-10037 
Poon, W.-C. (2010), A Monetary Policy rule: the Augmented Monetary Conditions Index for Philippines using UECM and bounds tests, Discussion Paper, No. 04/10, Monash University, Melbourne.

Rosenstein-Rodan, P. N. (1943), Industrialization of Eastern and South Eastern Europe. Economic Journal, $\mathrm{N}^{\circ} 53$, june-september.

Sachs, J. and Warner, A. M. (1997), Sources of slow growth in African economies, Journal of African Economies, Vol. 6, N 3, pp. 335-376.

Solow, R. (1956), A Contribution to the Theory of Economic Growth, Quarterly Journal of Economics, Vol. 70, $\mathrm{N}^{\circ}$ 1, pp. 65-94.

Tadaro, M. P. (1999), Economic Development, $7^{\text {th }}$ Edition, Addison Webley Longman Inc. Reading Massachusetts.

UNCTAD (2000), Capital Flows and Growth in Africa, UNCTAD/GDS/MDPB/7, Geneva

Willmore, L. N. (1986), The Comparative Performance of Foreign and Domestic Firms in Brazil, World Development, Vol. 14, N4, pp. 489-502.

World Bank (2005), Improving the Investment Climate, World Development Report 2005, World Bank. 